Jawetz, E., Gunnison, J. B. \& Coleman, V. R. (1954). J.gen. Microbiol. 10, 191-198.

\title{
Observations on the Mode of Action of Antibiotic Synergism and Antagonism
}

\author{
BY E. JAWETZ, JANET B. GUNNISON \\ AND VIRGINIA R. COLEMAN \\ Department of Microbiology, University of California School of Medicine, \\ San Francisco 22, California, U.S.A.
}

\begin{abstract}
SUMMARY: Inactive analogues and degradation products of active antibiotics failed to participate in either synergistic or antagonistic antimicrobial action in combination with active antibiotics. Streptobiosamine hydrochloride contaminated with $2-3 \%(w / w)$ streptomycin was synergistic with other antibiotics because of the active streptomycin present. The ratio of the smallest amount of antibiotic participating in synergism to that having independent antimicrobial activity varied with the drug and the micro-organism. Synergism with another antibiotic usually required from $1 / 20$ to $1 / 3$ of the minimal inhibitory concentration of an antibiotic when acting alone. Streptomycin, however, in 1/1000 of the minimal inhibitory concentration was synergistic with penicillin in its action on a strain of Streptococcus faecalis.
\end{abstract}

The combined effect of two antibiotics upon a bacterial population may be greater or less than that of either alone. One manifestation of such combined action is an alteration of the early bactericidal rate. A marked increase in the rate of bactericidal action of a pair of antibiotics above that achieved by a single drug may be called 'synergism'; a marked decrease, 'antagonism'. The experimental basis of combined action and its application have been summarized recently (Jawetz \& Gunnison, 1953). It has been postulated that antibiotic synergism and antagonism are the results of specific drug action on metabolic pathways which are essential for synthesis and growth. Antagonism has been observed only when the interfering antibiotic was used in a concentration having at least a bacteriostatic effect when acting alone (Gunnison, Coleman \& Jawetz, 1950). Hence, it seemed unlikely that chemical analogues and degradation products of antibiotics lacking in antimicrobial effect would interfere with the active antibiotics. In synergism, on the other hand, only one of a pair of antibiotics need exhibit independent antimicrobial action at the concentration employed in the combination (Jawetz, Gunnison \& Coleman, 1950; Chabbert, 1953). It was therefore possible that analogues and degradation products might enter into synergistic combinations even though themselves devoid of antimicrobial action. This paper records the results obtained with combinations of inactive analogues or degradation products and active antibiotics and also observations on quantitative aspects of synergism in vitro.

\section{MATERIALS AND METHODS}

Antibiotics and other compounds. The substances tested were: $(a)$ chlortetracycline hydrochloride (aureomycin, Lederle) in freshly prepared solution, and in a form partially inactivated by heating $200 \mu \mathrm{g}$. aureomycin $/ \mathrm{ml}$. in $0.85 \%$ 
$(\mathrm{w} / \mathrm{v})$ sodium chloride solution at $\mathrm{pH} 8$ at $\mathbf{7 2}^{\circ}$ for $13 \mathrm{hr}$. in a water-bath until less than 1/100 of the original activity remained; $(b)$ bacitracin (Pfizer); (c) chloramphenicol (Parke, Davis) and a biologically inactive isomer from its D-base; $(d)$ potassium penicillin $\mathbf{G}$ and the degradation products penicillamine hydrochloride and isopropyllidine penicillamine hydrochloride; $(e)$ streptomycin sulphate and the degradation products streptamine dihydrochloride, streptidine sulphate, and streptobiosamine dihydrochloride; $(f)$ oxytetracycline hydrochloride (terramycin, Pfizer); (g) erythromycin (Abbott). Stock solutions of these substances were prepared by dissolving weighed amounts in $0.85 \%(\mathrm{w} / \mathrm{v})$ sodium chloride solution. These were sterilized by Seitz filtration and stored at $-\mathbf{2 0} 0^{\circ}$. Final dilutions were freshly prepared in broth. All active antibiotics except bacitracin were pure crystalline materials and their activity is therefore expressed in $\mu \mathrm{g} . / \mathrm{ml}$. The bacitracin preparation was impure and its activity is expressed in units. The penicillin preparation contained 1600 units/mg.

Media. Proteose peptone no. 3 (Difco) broth of the following composition was used: Proteose peptone no. 3, 20 g.; glucose, 0.5 g.; sodium chloride, 5 g.; disodium phosphate $\left(\mathrm{Na}_{2} \mathrm{HPO}_{4} \cdot \mathbf{1 2} \mathrm{H}_{2} \mathrm{O}\right), 5 \mathrm{~g}$; water, $1000 \mathrm{ml}$; $\mathrm{pH} \mathbf{7 \cdot 2}$. Proteose no. 3 agar (Difco) was used for plate cultures.

Organisms used. Klebsiella pneumoniae (strain AD), Streptococcus faecalis (strain 16) and Staphylococcus aureus (strains Heatley, De, Co, and Er) were used as test bacteria.

Procedure. Broth containing the diluted antibiotics, analogues or degradation products, alone or in combination, was inoculated with an $18 \mathrm{hr}$. broth culture of the test bacteria to give a concentration of $10^{7}$ to $10^{8}$ organisms $/ \mathrm{ml}$. in a total volume of $15 \mathrm{ml}$. Samples of $0.5 \mathrm{ml}$. were removed at frequent intervals during incubation at $37^{\circ}$. The number of viable bacteria was estimated by plate counts. Details of the method have been described (Gunnison, Jawetz \& Coleman, 1950). Only differences in the number of bacteria greater than tenfold ( $1 \log$ unit) were regarded as significant. The smallest amount of drug which resulted in a bacterial count significantly lower than that in the drug-free control in at least two successive determinations at any time during $\mathbf{8 0} \mathbf{~ h r}$. of exposure to the drug was designated as the 'minimal effective dose' (M.E.D.).

\section{RESULTS}

Biologically active aureomycin was antagonistic to penicillin when acting on $K$. pneumoniae (Gunnison, Coleman \& Jawetz, 1950). The addition of bacteriostatic amounts of aureomycin $(0 \cdot 1-5 \cdot 0 \mu \mathrm{g} . / \mathrm{ml}$.) to rapidly bactericidal amounts of penicillin resulted in a marked decrease in the bactericidal rate. Smaller amounts of aureomycin (0.01-0.05 $\mu \mathrm{g} . / \mathrm{ml}$.), devoid of antimicrobial action, showed no such antagonism. Aureomycin inactivated by heating, in any concentration, likewise failed to interfere with the action of penicillin (Table 1).

Chloramphenicol interfered with the rapid lethal action of penicillin on many bacteria (Jawetz, Gunnison, Speck \& Coleman, 1951). The biologically inactive isomer from the D-base showed no antagonism (Table 1). Chloramphenicol was synergistic with streptomycin in its action against Staph. aureus 
Heatley, but the isomer from the $\mathrm{D}$-base could not be substituted for the active chloramphenicol.

Penicillin and streptomycin were markedly synergistic against $K$. pneumoniae and Strep. faecalis. In these synergistic systems, penicillamine hydrochloride or isopropyllidine hydrochloride, both without antimicrobial effect, could not be substituted in any concentration for active penicillin.

Streptamine dihydrochloride and streptidine sulphate had no demonstrable bacteriostatic action and could not take the place of streptomycin in synergistic combinations with either penicillin or bacitracin acting on any of the test organisms (Table 1). Streptomycin was synergistic with terramycin against Staph. aureus De, but neither streptidine nor streptamine in any concentration could be substituted for the active streptomycin. Streptobiosamine hydrochloride, on the other hand, showed clear-cut synergism when combined with penicillin acting on Strep. faecalis or with bacitracin acting on Staph. aureus Heatley (Table 1). In concentrations up to $250 \mu \mathrm{g} . / \mathrm{ml}$., streptobiosamine alone was as completely devoid of antibacterial action against Strep. faecalis as were streptidine and streptamine. However, $25 \mu \mathrm{g}$. streptobiosamine $/ \mathrm{ml}$. in combination with $6 \mu \mathrm{g}$. penicillin $/ \mathrm{ml}$. gave as striking synergism against Strep. faecalis as did streptomycin itself. In several other systems, streptobiosamine showed an additive effect of lesser magnitude.

Although streptobiosamine alone in concentrations up to $100 \mu \mathrm{g}$. $/ \mathrm{ml}$. had no demonstrable effect upon any of the test bacteria, in a dose of $250 \mu \mathrm{g} . / \mathrm{ml}$. it produced a slight transitory inhibition of the growth of Staph. aureus De, less than that shown by one M.E.D. of streptomycin. It was suspected, therefore, that it might contain traces of active streptomycin. Upon inquiry, Dr O. Wintersteiner, in whose laboratories the streptobiosamine had been prepared, stated that it was probably contaminated with $2-3 \%$ (w/w) of active streptomycin. If this contamination were responsible for the marked synergism observed, then small amounts of streptomycin, far less than the M.E.D., must be capable of participating in synergistic combinations. Accordingly, quantitative tests were made of several synergistic pairs to ascertain how small a proportion of an independently effective amount of antibiotic might enter into synergism.

A variety of systems was tested in which synergism conforming to the following definition occurred: 'The addition of one drug to another results in a marked increase in bactericidal rate within the first 8-24 hr. of exposure in vitro, and the bactericidal rate of the combination is more rapid than twice the concentration of each single drug participating in the mixture' (Jawetz \& Gunnison, 1953). In such systems, synergism regularly occurred when each member of the drug pair was present in a minimum effective dose (M.E.D.) which alone resulted in mere inhibition of growth (Table 2). Moreover, synergism also occurred when fractions of the M.E.D. of one antibiotic were combined with an M.E.D. of the other, i.e. an ineffective amount of one drug plus a barely active amount of the other might be synergistic (Table 2). Decreasing amounts of each drug were therefore combined with one M.E.D. of the other to determine how small a fraction might participate in synergism. 
When penicillin and streptomycin acted on $K$. pneumoniae, there was no synergism when the concentration of either drug was below 1/3 M.E.D. (Table 2). Although a concentration of $5 \mu \mathrm{g}$. streptomycin $/ \mathrm{ml}$. participated in synergism, $1 \mu \mathrm{g} . / \mathrm{ml}$. failed to so do. With streptobiosamine, a concentration of $50 \mu \mathrm{g} . / \mathrm{ml}$., containing $1 \cdot 0-1.5 \mu \mathrm{g}$. streptomycin $/ \mathrm{ml}$. as impurity, gave a slight additive

Table 1. Participation of analogues and degradation products of antibiotics in synergism and antagonism

\begin{tabular}{|c|c|c|c|c|c|c|}
\hline \multirow{4}{*}{$\begin{array}{c}\text { Test } \\
\text { organism } \\
\text { K. pneumoniae }\end{array}$} & \multicolumn{6}{|c|}{ Period after inoculation (hr.) } \\
\hline & \multirow{2}{*}{$\begin{array}{c}\text { Antibiotics or } \\
\text { preparations thereof } \\
(\mu \mathrm{g} . / \mathrm{ml} .)\end{array}$} & 0 & 2 & 7 & 24 & \multirow{2}{*}{$\begin{array}{c}\text { Combined } \\
\text { effect }\end{array}$} \\
\hline & & \multicolumn{4}{|c|}{ Number of viable bacteria $/ \mathrm{ml}$. } & \\
\hline & & $2 \times \overparen{10^{7}}$ & $10^{8}$ & $5 \times 10^{8}$ & $9 \times 10^{8}$ & - \\
\hline \multirow[t]{9}{*}{$\mathbf{A D}$} & Penicillin $\mathbf{1 2} \cdot 0$ & & $5 \times 10^{6}$ & $10^{2}$ & $<10^{1}$ & - \\
\hline & Chloramphenicol $1 \cdot 0$ & & $7 \times 10^{6}$ & $8 \times 10^{6}$ & $10^{7}$ & - \\
\hline & Pen. $12 \cdot 0+$ chlor. $1 \cdot 0$ & & $10^{7}$ & $2 \times 10^{5}$ & $7 \times 10^{3}$ & Antagonism \\
\hline & $\begin{array}{l}\text { Inactive chlor. } \\
\text { isomer } 1 \cdot 0\end{array}$ & & $10^{8}$ & $3 \times 10^{8}$ & $10^{9}$ & - \\
\hline & $\begin{array}{l}\text { Pen. } 12 \cdot 0+\text { chlor. } \\
\text { isomer } 1 \cdot 0\end{array}$ & & $2 \times 10^{6}$ & $3 \times 10^{2}$ & $<10^{1}$ & No antagonism \\
\hline & Aureomycin 1.0 & & $10^{7}$ & $2 \times 10^{4}$ & $1 \times 10^{8}$ & - \\
\hline & Pen. $12 \cdot 0$ + aureo. $1 \cdot 0$ & & $6 \times 10^{6}$ & $4 \times 10^{4}$ & $4 \times 10^{3}$ & Antagonism \\
\hline & $\begin{array}{l}\text { Inactive aureo., } \\
\text { heated } 10 \cdot 0\end{array}$ & & $8 \times 10^{7}$ & $2 \times 10^{8}$ & $9 \times 10^{8}$ & - \\
\hline & $\begin{array}{l}\text { Pen. } 12 \cdot 0+\text { aureo., } \\
\text { heated } 10 \cdot 0\end{array}$ & & $3 \times 10^{6}$ & $3 \times 10^{2}$ & $<10^{1}$ & No antagonism \\
\hline \multirow{6}{*}{$\begin{array}{l}\text { Staph. aureus } \\
\text { Heatley }\end{array}$} & None & $9 \times 10^{6}$ & $6 \times 10^{7}$ & $2 \times 10^{8}$ & $>10^{9}$ & - \\
\hline & Bacitracin $4 \cdot 0^{*}$ & & $8 \times 10^{7}$ & $5 \times 10^{8}$ & $4 \times 10^{4}$ & - \\
\hline & Streptidine $\mathbf{2 5 0 \cdot 0}$ & & $4 \times 10^{8}$ & $5 \times 10^{8}$ & $>10^{9}$ & - \\
\hline & $\begin{array}{l}\text { Baci. } 4 \cdot 0^{*}+\text { strepti- } \\
\text { dine } 250 \cdot 0\end{array}$ & & $3 \times 10^{7}$ & $5 \times 10^{6}$ & $9 \times 10^{3}$ & No synergism \\
\hline & $\begin{array}{l}\text { Streptobiosamine } \\
\mathbf{2 5 0 \cdot 0}\end{array}$ & & $6 \times 10^{7}$ & $3 \times 10^{8}$ & $>10^{9}$ & - \\
\hline & $\begin{array}{l}\text { Baci. } 4 \cdot 0^{*}+\text { strepto- } \\
\text { bios. } 250 \cdot 0\end{array}$ & & $10^{i}$ & $2 \times 10^{5}$ & $3 \times 10^{1}$ & Synergism \\
\hline \multirow{6}{*}{$\begin{array}{l}\text { Strep. faecalis } \\
16\end{array}$} & None & $3 \times 10^{7}$ & $9 \times 10^{7}$ & $5 \times 10^{8}$ & $>10^{9}$ & - \\
\hline & Penicillin $6 \cdot 0$ & & $9 \times 10^{6}$ & $4 \times 10^{5}$ & $\mathbf{3} \times 10^{4}$ & — \\
\hline & Streptomycin $\mathbf{2 5 \cdot 0}$ & & $10^{8}$ & $4 \times 10^{8}$ & $3 \times 10^{8}$ & - \\
\hline & $\begin{array}{l}\text { Pen. } 6 \cdot 0+\text { strepto. } \\
25 \cdot 0\end{array}$ & & $5 \times 10^{5}$ & $7 \times 10^{3}$ & $10^{2}$ & Synergism \\
\hline & $\begin{array}{l}\text { Streptobiosamine } \\
250 \cdot 0\end{array}$ & & $10^{8}$ & $6 \times 10^{8}$ & $>10^{9}$ & - \\
\hline & $\begin{array}{l}\text { Pen. } 6 \cdot 0+\text { strepto- } \\
\text { bios. } 250 \cdot 0\end{array}$ & & $2 \times 10^{6}$ & $3 \times 10^{4}$ & $7 \times 10^{2}$ & Synergism \\
\hline
\end{tabular}

effect with penicillin. Using Staph. aureus De as test organism, 1/5 M.E.D. of streptomycin $(4 \mu \mathrm{g} . / \mathrm{ml}$.) or $1 / 4$ M.E.D. of oxytetracycline were the smallest amounts resulting in synergism with 1 M.E.D. of the other drug (Table 2). When streptobiosamine was substituted for streptomycin, a concentration of $250 \mu \mathrm{g} . / \mathrm{ml}$., containing $5 \cdot 0-7 \cdot 5 \mu \mathrm{g} . / \mathrm{ml}$. of streptomycin, gave an additive effect, but 1/10 of this amount did not enter into combined action. These results, therefore, were consistent with the assumption that the activity shown by the streptobiosamine preparation was due to the streptomycin present. 
Similar dose relationships were observed in the following systems: bacitracin + streptomycin, acting on Staph. aureus Co (Table 2); bacitracin + erythromycin (Fig. 1) or bacitracin + chloramphenicol, acting on Staph. aureus Er; penicillin + bacitracin, penicillin + streptomycin, or bacitracin + streptomycin, acting on Staph. aureus Heatley; and bacitracin + streptomycin or penicillin + bacitracin acting on Strep. faecalis. In all these systems, fractions smaller than $1 / 20$ to $1 / 3$ of the M.E.D. of one drug failed to show synergism with one M.E.D. or more of the second drug.

Table 2. Relationship between antibiotic concentrations giving independent inhibition of growth and concentrations able to participate in synergistic combinations

\begin{tabular}{|c|c|c|c|c|c|c|c|}
\hline \multirow{3}{*}{$\begin{array}{l}\text { Test organism } \\
\text { Staph. aureus } \\
\text { Co }\end{array}$} & \multirow[b]{2}{*}{$\begin{array}{c}\text { Antibiotics } \\
(\mu \mathrm{g} . / \mathrm{ml} .)\end{array}$} & \multicolumn{4}{|c|}{ Period after inoculation (hr.) } & \multirow{2}{*}{$\begin{array}{l}\text { Minimum } \\
\text { effective } \\
\text { dose of } \\
\text { single drugs }\end{array}$} & \multirow{2}{*}{$\begin{array}{l}\text { Combined } \\
\text { effect }\end{array}$} \\
\hline & & $\begin{array}{l}0 \\
\text { Numb }\end{array}$ & $\stackrel{2}{\text { er of via }}$ & $\stackrel{7}{7}$ & $\begin{array}{c}24 \\
\mathrm{ria} / \mathrm{ml}\end{array}$ & & \\
\hline & $\begin{array}{l}\text { None } \\
\text { Bacitracin } 2 \cdot 0^{*} \\
\text { Streptomycin } 20 \cdot 0 \\
\text { Baci. } 2 \cdot 0^{*}+\text { strepto. } 2 \cdot 0 \\
\text { Baci. } 2 \cdot 0^{*}+\text { strepto. } 1 \cdot 0 \\
\text { Baci. } 0 \cdot 5^{*}+\text { strepto. } 20 \cdot 0 \\
\text { Baci. } 0 \cdot 2^{*}+\text { strepto. } 20 \cdot 0\end{array}$ & $4 \times 10^{7}$ & $\begin{array}{r}8 \times 10^{7} \\
8 \times 10^{6} \\
2 \times 10^{6} \\
10^{6} \\
4 \times 10^{6} \\
10^{4} \\
9 \times 10^{4}\end{array}$ & $\begin{array}{l}2 \times 10^{8} \\
5 \times 10^{5} \\
3 \times 10^{7} \\
2 \times 10^{3} \\
2 \times 10^{5} \\
5 \times 10^{2} \\
4 \times 10^{6}\end{array}$ & $\begin{array}{r}6 \times 10^{8} \\
5 \times 10^{6} \\
5 \times 10^{8} \\
10^{3} \\
10^{7} \\
2 \times 10^{2} \\
7 \times 10^{7}\end{array}$ & $\begin{array}{c}\overline{1} \\
1 \\
1+1 / 10 \\
1+1 / 20 \\
1 / 4+1 \\
1 / 10+1\end{array}$ & \begin{tabular}{l}
$\quad-$ \\
\multicolumn{1}{c}{-} \\
Synergism \\
No synergism \\
Synergism \\
No synergism
\end{tabular} \\
\hline $\begin{array}{l}\text { Staph. aureus } \\
\text { De }\end{array}$ & $\begin{array}{l}\text { None } \\
\text { Streptomycin } 20 \cdot 0 \\
\text { Terramycin } 2 \cdot 0 \\
\text { Terra. } 2 \cdot 0+\text { strepto. } 4 \cdot 0 \\
\text { Terra. } 2 \cdot 0+\text { strepto. } 2 \cdot 0 \\
\text { Terra. } 0 \cdot 5+\text { strepto. } 20 \cdot 0 \\
\text { Terra. } 0 \cdot 2+\text { strepto. } 20 \cdot 0\end{array}$ & $10^{7}$ & $\begin{array}{r}3 \times 10^{7} \\
3 \times 10^{4} \\
4 \times 10^{6} \\
10^{5} \\
6 \times 10^{6} \\
2 \times 10^{4} \\
10^{5}\end{array}$ & $\begin{array}{r}10^{8} \\
2 \times 10^{7} \\
5 \times 10^{5} \\
6 \times 10^{2} \\
7 \times 10^{4} \\
10^{2} \\
4 \times 10^{8}\end{array}$ & $\begin{array}{r}4 \times 10^{8} \\
3 \times 10^{8} \\
9 \times 10^{7} \\
10^{2} \\
8 \times 10^{5} \\
<10^{1} \\
>10^{8}\end{array}$ & $\begin{array}{c}\overline{1} \\
1 \\
1+1 / 5 \\
1+1 / 10 \\
1 / 4+1 \\
1 / 10+1\end{array}$ & $\begin{array}{l}- \\
- \\
\text { Synergism } \\
\text { No synergism } \\
\text { Synergism } \\
\text { No synergism }\end{array}$ \\
\hline $\begin{array}{l}\text { K. pneumoniae } \\
\text { AD }\end{array}$ & $\begin{array}{l}\text { None } \\
\text { Penicillin } 0 \cdot 6 \\
\text { Streptomycin } 5 \cdot 0 \\
\text { Pen. } 0 \cdot 6+\text { strepto. } 5 \cdot 0 \\
\text { Pen. } 0 \cdot 6+\text { strepto. } 1 \cdot 0 \\
\text { Pen. } 0 \cdot 15+\text { strepto. } 5 \cdot 0\end{array}$ & $9 \times 10^{6}$ & $\begin{array}{r}4 \times 10^{7} \\
3 \times 10^{6} \\
4 \times 10^{3} \\
4 \times 10^{2} \\
7 \times 10^{7} \\
10^{6}\end{array}$ & $\begin{array}{r}3 \times 10^{8} \\
7 \times 10^{6} \\
3 \times 10^{7} \\
10^{2} \\
5 \times 10^{6} \\
8 \times 10^{5}\end{array}$ & $\begin{array}{r}8 \times 10^{8} \\
5 \times 10^{6} \\
6 \times 10^{7} \\
<10^{1} \\
7 \times 10^{6} \\
2 \times 10^{6}\end{array}$ & $\begin{array}{c}\overline{1} \\
1 \\
1+1 \\
1+1 / 5 \\
1 / 4+1\end{array}$ & $\begin{array}{c}-- \\
- \\
\text { Synergism } \\
\text { No synergism } \\
\text { No synergism }\end{array}$ \\
\hline
\end{tabular}

* In units/ml.

The picture was different when the synergism of penicillin with streptomycin against Strep. faecalis was explored. This system exhibited several peculiarities. Penicillin showed an optimum zone phenomenon in its action on Strep. faecalis (Eagle, 1951). The bactericidal rate was greatest near concentrations of $6 \mu \mathrm{g} . / \mathrm{ml}$., and diminished with both larger and smaller concentrations of drug. Synergistic effects were conveniently tested at this optimum concentration of penicillin because the bactericidal rate was increased beyond the maximum obtainable with any concentration of the single drugs. Strep. faecalis 16 was very resistant to streptomycin alone; the M.E.D. was $300 \mu \mathrm{g}$. streptomycin/ml., no significant bactericidal action was observed with less than $500 \mu \mathrm{g}$./ml., and concentrations below $200 \mu \mathrm{g}$. $/ \mathrm{ml}$. had no observable action whatever. However, striking synergism occurred with $0 \cdot 3 \mu \mathrm{g}$. strepto- 
mycin/ml. (1/1000 M.E.D.) added to $6 \mu \mathrm{g}$. penicillin/ml. (Table 3, Fig. 1). Penicillin concentration could not be decreased correspondingly. With 1 M.E.D. of streptomycin, 1/10 of the optimal penicillin dose failed to give synergism. When the dose of penicillin was increased 25-fold over the optimum, and consequently the bactericidal rate diminished, synergism with streptomycin was likewise reduced (Table 3).

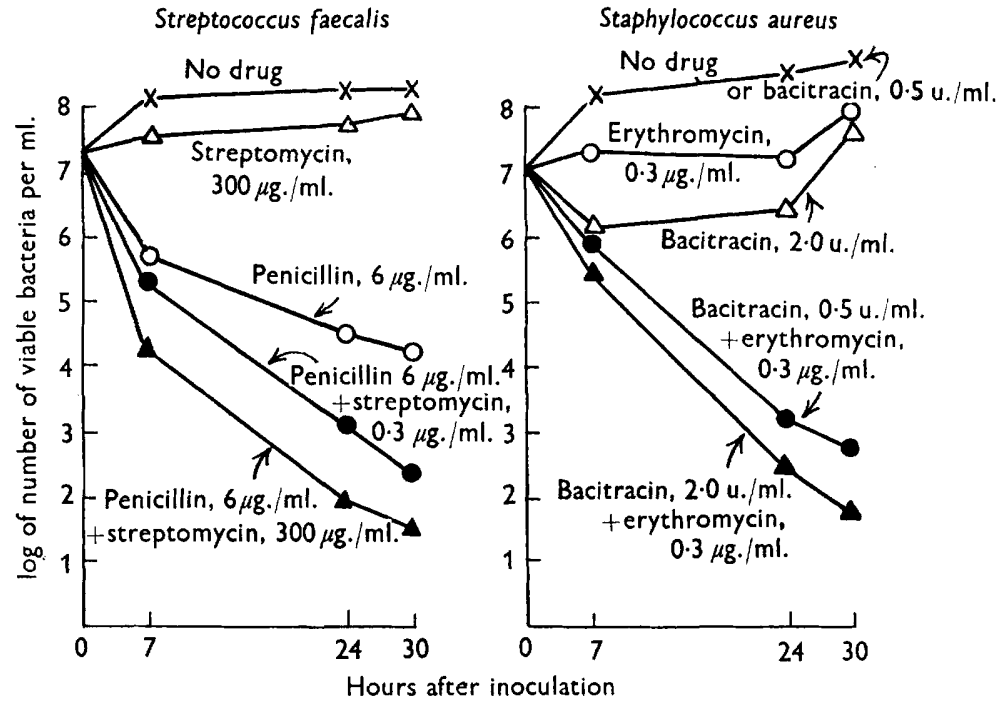

Fig. 1. Quantitative relationships in antibiotic synergism. Left: synergism of similar magnitude results from the combination of streptomycin in either a barely bacteriostatic concentration (300 $\mu \mathrm{g} . / \mathrm{ml}$ ) $)$ or in $1 / 1000$ of that amount $(0 \cdot 3 \mu \mathrm{g} . / \mathrm{ml}$.) with the optimal concentration of penicillin $(6 \mu \mathrm{g}$. $/ \mathrm{ml}$.). Right: synergism of similar magnitude results from the combination of bacitracin in either an inhibitory concentration (2 units $/ \mathrm{ml}$.) or in an ineffective amount $(0.5 \mathrm{units} / \mathrm{ml}$.) with a bacteriostatic concentration of erythromycin $(0.3 \mu \mathrm{g} . / \mathrm{ml}$.).

Table 3. Synergistic effects of varying proportions of penicillin and streptomycin acting on Streptococcus faecalis 16

Period after inoculation (hr.)
Antibiotics ( $\mu \mathrm{g} . / \mathrm{ml}$.)

None

Streptomycin $300 \cdot 0$

Penicillin 2.0

Pen. 0.6 + strepto. 300.0

Pen. 2.0 + strepto. 300.0

Pen. 2.0 + strepto. 3.0

Pen. $2 \cdot 0$ + strepto. $0 \cdot 3$

Penicillin $6 \cdot 0$

Pen. 6.0 + strepto. 3.0

Pen. 6.0 + strepto. 0.3

Pen. 6.0 + strepto. 0.1

Pen. 150.0

Pen. 150.0 + strepto. 15.0

Pen. 150.0 + strepto. 1.0

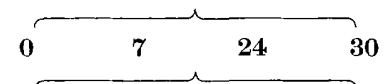

Number of viable bacteria $/ \mathrm{ml}$.

$\begin{array}{rrrrr}4 \times 10^{7} & 3 \times 10^{8} & 4 \times 10^{8} & 4 \times 10^{8} & - \\ & 8 \times 10^{6} & 5 \times 10^{6} & 10^{8} & 1 \\ 5 \times 10^{6} & 6 \times 10^{5} & 2 \times 10^{5} & 1 \\ 10^{6} & 6 \times 10^{6} & 3 \times 10^{7} & 3 / 5+1 \\ 4 \times 10^{5} & 5 \times 10^{2} & 10^{2} & 1+1 \\ 6 \times 10^{4} & 5 \times 10^{4} & 10^{4} & 1+1 / 100 \\ 10^{6} & 7 \times 10^{5} & 2 \times 10^{5} & 1+1 / 1,000 \\ & 7 \times 10^{5} & 4 \times 10^{4} & 2 \times 10^{4} & 3 \\ 5 \times 10^{4} & 8 \times 10^{2} & 3 \times 10^{2} & 3+1 / 100 \\ 3 \times 10^{5} & 10^{3} & 5 \times 10^{2} & 3+1 / 1,000 \\ 8 \times 10^{5} & 4 \times 10^{3} & 7 \times 10^{4} & 3+3 / 10,000 \\ 2 \times 10^{6} & 10^{5} & 7 \times 10^{4} & 75 \\ 6 \times 10^{4} & 6 \times 10^{2} & 9 \times 10^{1} & 75+1 / 20 \\ 3 \times 10^{6} & 2 \times 10^{5} & 4 \times 10^{4} & 75+3 / 1,000\end{array}$

Minimum effective dose of single drugs

Combined effect

No synergism Synergism Synergism No synergism

Synergism Synergism No synergism Synergism No synergism 


\section{DISCUSSION}

If it be assumed that antibiotic action is based on a metabolic block in biosynthetic pathways, then antibiotic antagonism may be pictured as follows, using the diagram proposed by Eagle (1951):

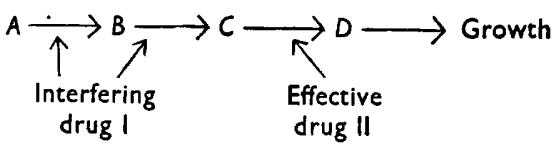

A drug (I) may interfere with the maximal effect of another drug (II) by partially blocking some metabolic process $(A \rightarrow B \rightarrow C)$ which is necessary for the optimal action of the 'effective' drug II. If interfering quantities of drug I are bacteriostatic then the slowing of multiplication might account for diminished effectiveness of drug II, e.g. penicillin which is most lethal for rapidly multiplying organisms. Thus bacteriostatic agents like chloramphenicol, chlortetracycline or oxytetracycline might be expected to antagonize penicillin, as indeed they do under certain circumstances. Reasons have been presented elsewhere, however, why bacteriostasis as such probably does not account for the phenomenon of antibiotic antagonism (Jawetz \& Gunnison, 1953). In all cases of antagonism studied, the interfering drug has some antimicrobial effect of its own. Thus it is not surprising that the biologically inactive antibiotic degradation products tested in the present study lacked interfering ability.

Antibiotic synergism may be schematically presented in the following way:

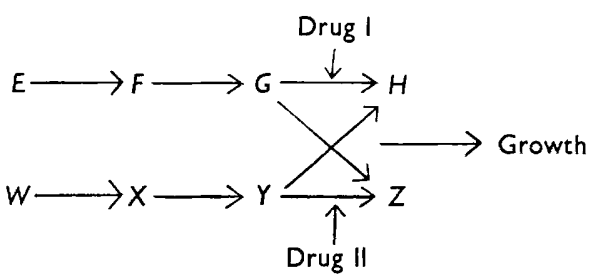

A micro-organism may be capable of bypassing a metabolic block produced by drug I in one pathway $(\boldsymbol{E} \rightarrow \boldsymbol{F} \rightarrow \boldsymbol{G} \rightarrow \boldsymbol{H})$; drug II then may act by blocking an alternate metabolic pathway $(W \rightarrow X \rightarrow Y \rightarrow Z)$. In the absence of inhibitory drugs, the micro-organism may utilize the biosynthetic processes $\boldsymbol{E} \rightarrow \boldsymbol{F} \rightarrow \boldsymbol{G} \rightarrow \boldsymbol{H}$ with high efficiency, but $\boldsymbol{W} \rightarrow \boldsymbol{X} \rightarrow \boldsymbol{Y} \rightarrow \boldsymbol{Z}$ with low efficiency. Thus a drug blocking $E \rightarrow F \rightarrow G \rightarrow H$ would appear to be inhibitory when acting alone, but a drug acting on $W \rightarrow X \rightarrow Y \rightarrow Z$ may not manifest its effect when present alone. Activity of drug II would be made manifest only by the presence of another inhibitory agent. It seemed plausible, therefore, that chemical substances which were devoid of independent antimicrobial activity might likewise participate in such combined action. The greatest opportunity for such a demonstration appeared to lie with compounds closely related chemically to active antibiotics. The results reported in this paper suggest that synergistic effects occur only with substances which possess 
independent antimicrobial action in some concentration. The ratio of the amount which is capable of participating in synergism to that which exhibits independent antimicrobial activity varies with each drug and each test microorganism, but is usually from $1 / 20$ to $1 / 3$ of the smallest quantity which gives slight, temporary inhibition of growth. Streptomycin presents a unique exception, because as little as $1 / 1000$ of the minimal effective concentration can sometimes participate in synergism, as Chabbert (1953) has also reported. It appears that streptomycin may affect a biosynthetic process which requires very high concentrations of the drug for complete block yet can be partially blocked by very small concentrations when another drug acts on the organism simultaneously. These results perhaps explain the frequency with which streptomycin participates in synergistic effects even against micro-organisms which appear to be resistant to high concentrations of the drug.

We are grateful to Dr O. Wintersteiner (Squibb Institute for Medical Research, New Brunswick, N.J., U.S.A.) and to Dr D. Rowley (Wright-Fleming Institute, St Mary's Hospital, London) for furnishing the degradation products of penicillin and streptomycin and for much helpful advice. Dr G. Rieveschl (Parke, Davis and Co., Detroit, Michigan) kindly supplied chloramphenicol and the biologically inactive isomer from the $\mathbf{D}$-base. This work was supported in part by a grant from the U.S. Public Health Service (E-214) and from the Research Committee of the University of California School of Medicine.

\section{REFERENCES}

Chabbert, Y. (1953). Action des associations d'antibiotiques sur les germes aerobies. Ann. Inst. Pasteur, 84, 545.

EAGLE, H. (1951). Further observations on the zone phenomenon in the bactericidal action of penicillin. J. Bact. 62, 663 .

Gunnison, J. B., Coleman, V. R. \& JAwEtz, E. (1950). Interference of aureomycin and of terramycin with action of penicillin in vitro. Proc. Soc. exp. Biol., N.Y. 75, 549.

Gunnison, J. B., Jawetz, E. \& Coleman, V. R. (1950). The effect of combinations of antibiotics on enterococci in vitro. J. Lab. clin. Med. 36, 900.

JAwETz, E. \& Gunnison, J. B. (1953). Antibiotic synergism and antagonism: An assessment of the problem. Pharm. Rev. 5, 175.

Jawetz, E., Gunnison, J. B. \& Coleman, V. R. (1950). The combined action of penicillin with streptomycin or chloromycetin on enterococci in vitro. Science, 111, 254 .

Jawetz, E., Gunnison, J. B., Speck, R. S. \& Coleman, V. R. (1951). Studies on antibiotic synergism and antagonism. The interference of chloramphenicol with the action of penicillin. Arch. intern. Med. 87, 349.

(Received 7 August 1953) 